\title{
Hipotetyczne przyczyny nieregularnego zużycia kół w wagonach metra typu "Metropolis" na podstawie badań rozpoznawczych roku 2002
}

\author{
Opisano realizowane w 2002 r. badania taboru typu „,Metropolis”, na podstawie których sformuło- \\ wano szereg hipotez dotyczacych przyczyn powstawania zjawiska nieregularnego zużycia kół.
}

\section{Wstęp}

Metro Warszawskie eksploatuje dwa różne typy taboru szynowego. Od kwietnia 1995 roku tabor produkcji rosyjskiej oraz od końca 2000 r. nowoczesne, 6-wagonowe pociagi typu „Metropolis” firmy ALSTOM (początkowo 4 pociągi, uzupełnione $\mathrm{w}$ roku 2001 do ośmiu). W rezultacie w roku 2002 w użytkowaniu znajdowało się, oprócz wspomnianych ośmiu, piętnaście 4-wagonowych pociągów produkcji rosyjskiej.

Trudne warunki geologiczne i przebieg eksploatowanej sieci w gęsto zabudowanej oraz zaludnionej aglomeracji spowodowały, że władze miasta i Metro Warszawskie wdrożyły system monitoringu drgań sejsmicznych dla wybranych 12 budynków mieszkalnych, leżących wzdłuż trasy metra. Z jego pomocą okresowo sprawdzano wpływ i skutki eksploatacji metra na budynki oraz ludzi w nich przebywających.

Nasilające się w końcu roku 2001 informacje o wzroście uciążliwości metra spowodowały uruchomienie systemu, dzięki czemu ustalono, że:

- podczas przejazdów taboru typu „Metropolis” w monitorowanych punktach systemu następuje przekroczenie wyznaczonej normą PN-88/B02171 granicy dopuszczalnych drgań na organizmy ludzkie,

- zarejestrowane drgania, w odniesieniu do budynków, nie przekraczają granicy A wg normy PN85/B-02170.

- $\quad$ istnieje przyczynowy związek pomiędzy wyżej omówionymi drganiami a taborem typu „Metropolis".

Powyższe ustalenia ujęto we wnioskach podsumowujących badania Politechniki Krakowskiej p.t.: „Badania wpływu drgań wywołanych przejazdami pociagów metra produkcji rosyjskiej i produkcji firmy ALSTOM na wybrane budynki przy al. Niepodległości i ul. Waryńskiego oraz na ludzi przebywających w tych budynkach"

Biorąc pod uwagę okresy eksploatacyjne obu rodzajów taboru w tym wyłączny, 5-letni, okres użytkowania tylko pojazdów rosyjskich, jest rzeczą wysoce prawdopodobną, że przyczyny istniejącego stanu rzeczy mogą tkwić w:

- $\quad$ obsłudze eksploatacyjnej, niezgodnej z wymaganiami producenta zdefiniowanymi $\mathrm{w}$ dokumentacji techniczno-ruchowej lub

- $\quad$ konstrukcji pojazdów „Metropolis”, nie spełniającej eksploatacyjnych oczekiwań producenta, zdefiniowanych $\mathrm{w}$ jego własnej dokumentacji techniczno- ruchowej.

Stała obecność serwisu obsługowego firmy ALSTOM w bazie Metra Warszawskiego - Kabaty i brak sygnałów o zasadniczych niedociagnięciach obsługowych ze strony Użytkownika wykluczyły pierwszą z możliwych przyczyn.
Można więc domniemywać, że:

- $\quad$ wymagane przez producenta cykle obsługowe nie odpowiadają jakości konstrukcyjnej taboru, a ich stosowanie prowadzi do makroskutków określonych badaniami Politechniki Krakowskiej,

- $\quad$ istnieje negatywny wpływ stosowanych procedur obsługowych producenta na jakość techniczną taboru i związane z tym zagadnienia bezpieczeństwa eksploatacyjnego.

Pożądaną zmianę istniejącego stanu można osiągnąć zmieniając istniejące procedury obsługowe na odpowiadające rzeczywistym możliwościom technicznym taboru, albo modyfikując konstrukcję pojazdu tak, aby stosowanie istniejących procedur obsługowych nie pogarszało jakości technicznej pojazdów. Wybór drogi postępowania, zakres koniecznych zmian i ich wpływ na bezpieczeństwo eksploatacyjne należało uzależnić od wyników badań technicznych o charakterze wyjaśniającym przyczyny ww zjawisk.

W tym stanie rzeczy, w wyniku uzgodnień zainteresowanych stron, zrealizowano szereg technicznych badań rozpoznawczych, których wyniki stanowiły podstawę opisanej w artykule pracy, jaką na rzecz Metra Warszawskiego zrealizował IPS „TABOR” w 2002 roku.

\section{Wyznaczone cele i zakres pracy}

Wyznaczonym celem pracy była analiza i ocena pozyskanego materiału badawczego pod kątem występującego zjawiska drgań i nieregularnego zużycia kół w wagonach metra typu "Metropolis" w następującym zakresie:

- wyników badań i pomiarów,

- ustalenia przyczyn powstawania uszkodzeń,

- oceny i wniosków co do możliwości eksploatacyjnych zestawów kołowych na podstawie istniejących wyników badań i opinii niezależnych ekspertów/a w zakresie wpływu drgań i stwierdzonych parametrów wytrzymałościowych na własności trybologiczne zestawów kołowych,

ewentualnych zmian konstrukcyjnych.

\section{Identyfikacja dokumentacji badawczej i obiektów}

3.1 Dokumentacja badawcza wg tabeli 1 .

\subsection{Identyfikacja obiektów $\mathrm{z}$ materiałami badawczymi} $\mathrm{Z}$ uwagi na różnych Wykonawców badań i obserwacji oraz różne $\mathrm{w}$ związku $\mathrm{z}$ tym sposoby identyfikacji wyników badań z obiektami, z przyczyn praktycznych opracowano w tabeli 2 identyfikację zbiorczą. Wynika z niej, że dla części materiału badawczego identyfikacja: wynik - obiekt była niemożliwa. W związku z tym materiał taki w dalszym ciagu pracy był traktowany jako informacyjny, nie wpływający na ostateczne wnioski i postulaty. 


\begin{tabular}{|c|c|c|c|c|}
\hline \multicolumn{5}{|c|}{ Materialy producenta taboru typu „Metropolis” } \\
\hline Lp. & Numer & Tytul & Autor (jednostka/osoba) & $\begin{array}{l}\text { Data opraco- } \\
\text { wania }\end{array}$ \\
\hline 1 & 2 & 3 & 4 & 5 \\
\hline 1 & & $\begin{array}{c}\text { Program badawczy w zakresie dynamiki } \\
\text { taboru Metropolis }\end{array}$ & prof. Jerzy Madej & kwiecień 2002 \\
\hline & $\begin{array}{c}501 / \mathrm{E} / 4438 / 1 \\
100 / 000\end{array}$ & $\begin{array}{l}\text { Wykonanie badań związanych z analizą } \\
\text { przyczyn nierównomiernego wyrabiania się } \\
\text { obwodów kół wagonów Metropolis }\end{array}$ & $\begin{array}{l}\text { Politechnika Warszawska } \\
\text { Uczelniane Centrum Ba- } \\
\text { dawcze. Materiały funk- } \\
\text { cjonalne }\end{array}$ & maj 2002 \\
\hline & $\mathrm{RP}-0085$ & $\begin{array}{l}\text { Badania przyspieszenia, przemieszczenia, } \\
\text { drgań oraz sił } \mathrm{H} \text { na wagonie sterującym } \\
\text { (tocznym) pociagu nr } 20 \text { "Metropolis" }\end{array}$ & IPS "TABOR" & luty 2002 \\
\hline & OR - 8452 & $\begin{array}{c}\text { Ocena właściwości biegowych wagonów } \\
\text { pociagu "Metropolis" oraz analiza wibracji } \\
\text { zestawów kołowych i toru w tunelu Metro - } \\
\text { Warszawa } \\
\end{array}$ & IPS "TABOR" & luty 2002 \\
\hline & SB - 2185 & $\begin{array}{c}\text { Kontrola prawidłowości montażu wózków } \\
\text { pod wagonami pociagu "Metropolis" Metra } \\
\text { Warszawskiego. Pomiary geometrii } \\
\end{array}$ & IPS "TABOR" & luty 2002 \\
\hline 6 & Fax & $\begin{array}{c}\text { Komentarz do wyników z raportu pomiarów } \\
\text { naprężeń kół metodą ultra- } \\
\text { dźwiękowa }\end{array}$ & ALSTOM & - \\
\hline & $\begin{array}{l}\text { Memoran- } \\
\text { dum }\end{array}$ & $\begin{array}{c}\text { Pomiar twardości koła nr } 20 \text { Metra Warszaw- } \\
\text { skiego }\end{array}$ & ALSTOM & $\begin{array}{l}\text { 05-kwiecień } \\
2002 \\
\end{array}$ \\
\hline 8 & Szkic & Obliczenia sztywności wózka & ALSTOM & - \\
\hline & $\begin{array}{l}\text { Raport nr } \\
18040101\end{array}$ & $\begin{array}{c}\text { Związek pomiędzy uszkodzeniami kół, a } \\
\text { usterkami hamulca elektrycznego i pneuma- } \\
\text { tycznego }\end{array}$ & ALSTOM & 09-maj-2002 \\
\hline 10 & Wykresy & $\begin{array}{l}\text { Zużycie grubości obrzeża. } \\
\text { Proces zużycia koła-reprofilacja }\end{array}$ & $\begin{array}{l}\text { wykresy nie autoryzowa- } \\
\text { ne (ALSTOM), nie przy- } \\
\text { porządkowane kołom lub } \\
\text { pociagom } \\
\end{array}$ & - \\
\hline 11 & List & $\begin{array}{c}\text { Ekspertyza zestawów kołowych Metra War- } \\
\text { szawskiego }\end{array}$ & SNCF & $\begin{array}{l}\text { 24-kwiecień } \\
2002 \\
\end{array}$ \\
\hline 12) & Opracowanie & $\begin{array}{c}\text { Informacja wstępna w sprawie zużycia ze- } \\
\text { stawów kołowych typu Metropolis }\end{array}$ & Metro Warszawskie & kwiecień 2002 \\
\hline (13) & Protokół & Pomiar twardości kół & Metro Warszawskie & - \\
\hline
\end{tabular}

Uwaga: W tabeli 1 i 2 materialy o petnej identyfikacji zostaly oznaczone

\section{Ocena zrealizowanych badań i pomiarów}

Oceniając na podstawie przekazanych materiałów kierunek prowadzonych badań:

- dynamika według wymagań UIC i geometria taboru - prezentowany przez raport nr RP-0085, sprawozdanie SB-2185 i opracowanie OR-8452,

- $\quad$ struktura, właściwości mechaniczne i naprężenia własne kół z uwzględnieniem wymagań UIC prezentowany przez sprawozdanie 501/E/4438/ $1100 / 000$

odnotowano jego zbieżność z konkluzjami wynikającymi $\mathrm{z}$ dokonanego we wstępie przeglądu sytuacji na tle siedmioletnich doświadczeń eksploatacyjnych Metra Warszawskiego.

Oznaczało to, że przyczyny nieprawidłowości eksploatacyjnych tkwią $\mathrm{w}$ szeroko pojętym związku zagadnień konstrukcyjnych taboru $\mathrm{z}$ wymaganymi procedurami obsługowymi, a ich usunięcie jest możliwe poprzez odpowiednią modyfikację jednego lub obu czynników. Podjęcie decyzji uzależnione zostało od wyników zadysponowanych badań rozpoznawczych i informacji zawartych w materiałach pomocniczych w postaci:
- zidentyfikowanych zestawień pomiarów geometrycznych i fizycznych,

- zidentyfikowanej statystyki serwisowej,

- materiałów informacyjnych.

Dla tak określonego celu przyjęty zakres i program badań wspomagany materiałami pomocniczymi był wystarczający do:

- rozpoznania przyczyn rozbieżności pomiędzy deklarowanymi a rzeczywistymi parametrami eksploatacyjnymi taboru produkcji firmy ALSTOM,

- ustalenia stopnia bezpieczeństwa eksploatacyjnego taboru,

- sformułowania w postaci tezy przyczyn leżących u podstaw zauważonych nieprawidłowości.

Nie było natomiast możliwe precyzyjne wskazanie kierunku pożądanych zmian konstrukcyjnych.

\section{Analiza wyników badań i pomiarów}

$\mathrm{Na}$ podstawie informacji zawartych w materiale badawczym ujętym w tab. 3 stwierdzono, że badania dynamiczne decydujące o bezpieczeństwie biegu pojazdu szynowego przeprowadzone były dla typowego stanu eksploatacyjnego 
taboru typu "Metropolis" tzn. dla stanu, w którym średnio ok. 40\% eksploatowanych kół wykazuje nieregularności obwodu tocznego, oraz dla stanu nominalnego po przetoczeniu zestawów kołowych.

W związku z powyższym, w oparciu o wyniki, uznano, że dla obu przypadków tabor typu "Metropolis" w zakresie bezpieczeństwa jazdy i stabilności biegu spełnia wymagania kart UIC 515 i UIC 518.

W zakresie wymagań szczegółowych, wymagań infrastrukturalnych oraz deklaracji technicznych producenta taboru, tabor typu "Metropolis" nie spełnia wymagań w następującym, udowodnionym badaniami zakresie:

1. Tabor w badanym stanie eksploatacyjnym jest przyczyną drgań sejsmicznych o poziomie przekraczającym wymagania normy PN/B-02171 w odniesieniu do organizmów ludzkich.

2. Eksploatacja taboru zgodna $\mathrm{z}$ technicznymi procedurami obsługowymi producenta powoduje samoczynną utratę kołowości powierzchni tocznej, objawiająca się wielokrotnym ukątnieniem koła (ok.6 $\div 9$ razy) powodującym przekroczenie dopuszczalnego bicia promieniowego, ustalonego polskimi przepisami eksploatacyjnymi OW-304. Z pomiarów pośrednich (pomiary twardości zweryfikowane wykresami bicia promieniowego) szacuje się, że powszechność zjawiska sięga ok. 40\% eksploatowanych zestawów kołowych.

3. Eksploatacja taboru zgodna $\mathrm{z}$ technicznymi procedurami obsługowymi producenta powoduje samoczynne utwardzanie lokalne powierzchni tocznej koła, powodujące różnicowanie twardości ponad dopuszczalną wielkość określoną kartą UIC 812-3. Maksymalna wykryta różnica wynosi 277 HB.

4. Zróżnicowana twardość powierzchni tocznej uniemożliwia prawidłowe wykonanie zabiegu technologicznego - przetaczanie kół zestawu.

5. Koła w stanie nowym i nie przetoczonym wykazują niepokojąco wysoki stan naprężeń własnych wynoszący skrajnie: $-330 \div-400 \mathrm{MPa}$ poprzez $260 \div-350 \mathrm{MPa}$ dla zestawów nowych oraz $-170 \div-$ $240 \mathrm{MPa}$ dla zestawów przetoczonych na głębokość promieniową $7 \mathrm{~mm}$.

Standard SNCF i PrEN ustala wymagania na poziomie $-80 \div-150 \mathrm{MPa}$.

Wymagania ustalone kartą UIC 812-3 określająca pośredni sposób i kryteria oceny są zaszłością historyczną wynikającą z ówczesnego braku nieniszczących metod pomiarowych i jako takie nie są na dzień dzisiejszy wystarczające z uwagi na to, że kontrolując maksymalny poziom naprężeń własnych nie ustalają poziomu naprężeń minimalnych.

6. Pojawiające się nieregularności powierzchni tocznej wymagają przetoczeń reprofilujących po przebiegach średnio o 50\% mniejszych od deklarowanego przez producenta. Tym samym nastąi przedwczesne zużycie zestawów kołowych w stosunku do zakładanego. Należy domniemywać, że wspomniane skrócenie przebiegu może ulec wzrostowi, ponieważ nie jest dopuszczalne eksploatowanie taboru od chwili, kiedy występują zjawiska ujęte powyżej w punktach 1 i 4.

\section{Hipotetyczne przyczyny nieprawidłowości eksplo- atacyjnych \\ Szczegółowa analiza wyników badań, zwłaszcza w za-} kresie wibracji zestawów kołowych (RP-0085, SB-2185) oraz naprężeń własnych (501E/4438/1100/000) pozwala, z uwagi na skomplikowany charakter techniczny zjawiska $\mathrm{i}$ charakter zrealizowanych badań, na hipotetyczne przedstawienie podstawowej przyczyny (praprzyczyny) nieprawidłowości eksploatacyjnych, za którą należy uważać nieregularne, wielokątne zużywanie się okręgów tocznych zestawów kołowych.

Jest prawdopodobne, że podstawowymi przyczynami są:

1. drgania poprzeczne zestawu kołowego z osadzonymi na osi ciężkimi tarczami hamulcowymi względem szyny o amplitudzie większej od amplitudy zestawu kołowego bez tarcz hamulcowych,

2. wysoki poziom wartości naprężeń własnych w kołach grożący lub powodujący utratę stateczności koła, a tym samym potęujący skutki wywołane drganiami poprzecznymi.

Jak wiadomo każde, nawet dopuszczalne nierówności toczącego się zestawu kołowego i toru po którym odbywa się bieg pojazdu oraz naturalne dla ruchu pojazdu szynowego wężykowanie, uruchamia proces wzbudzenia słabo gasnących drgań strukturalnych (giętnych) zestawu kołowego, które na styku koło-szyna przyjmują między innymi kierunek poprzeczny do osi toru. Generowane w ten sposób drgania są, w przypadku zestawów z osiowo osadzonymi tarczami hamulcowymi lub kołami przekładniowymi, wzmacniane, powodując wzrost amplitud drgań w stosunku do zestawu pozbawionego mas skupionych. Jak wykazała analiza modalna (OR-8452), amplitudy drgań poprzecznych zestawu "rosyjskiego" pozbawionego mas skupionych są o ok. 60\% mniejsze od amplitud kół pojazdu typu "Metropolis" przy prawie tym samym poziomie drgań własnych. Powstający efekt dodatkowo potęgować może lub potęguje druga $z$ wymienionych wyżej przyczyn. W rezultacie na zestawach z masami skupionymi zaczyna działać mechanizm przyspieszonych zużyć ukątnionych jaki ma miejsce na zestawach zastosowanych w taborze typu "Metropolis".

\section{Ocena stanu eksploatacyjnego taboru typu "Metro- polis" eksploatowanego w 2002 roku}

Analizę stanu prowadzono kierując się łącznie ustaleniami p. 5 i 6 oraz wstępną oceną zmierzonych naprężeń własnych.

W jej wyniku stwierdza się istnienie dwóch problemów:

1. naprężeń własnych w wyłącznym odniesieniu do bezpieczeństwa eksploatacji zestawów kołowych,

2. niekorzystnych skutków eksploatacyjnych opisanych i wymienionych w p. 5, a wywołanych łącznie wibracjami zestawów kołowych i naprężeniami własnymi.

Pierwsze zagadnienie i sposób jego rozwiązania w świetle omówionych kryteriów (pkt. 5, ppkt. 5), jest bezdyskusyjne, zwłaszcza w istniejących w okresie badań warunkach eksploatacyjnych. Oddziaływanie dynamiczne na koło zużyte eksploatacyjnie w nieprawidłowy sposób (należy zakładać, że dotyczy to $40 \%$ eksploatowanych kół) osiaga 20 krotny wzrost w stosunku do koła przetoczonego (RP0085).Powstający poziom naprężeń cyklicznie zmiennych, na który składają się wysoka dynamika i naprężenia własne, grozi uszkodzeniami zmęczeniowymi o nieprzewidywalnych w ostateczności skutkach. Konieczne jest więc 
Zestawienie materiału badawczego

\begin{tabular}{|c|c|c|c|c|c|c|}
\hline \multirow{2}{*}{$\begin{array}{l}\text { L. } \\
\text { p. }\end{array}$} & \multirow{2}{*}{$\begin{array}{l}\mathrm{Nr} \\
\text { dokumentac } \\
\text { ji badawczej }\end{array}$} & \multicolumn{2}{|c|}{ Cechy badanego obiektu } & \multirow[b]{2}{*}{ Badany parametr } & \multirow[b]{2}{*}{ Kryteria oceny } & \multirow[b]{2}{*}{ Wynik } \\
\hline & & Identyfikator & $\begin{array}{c}\text { Charakterystyczne } \\
\text { parametry }\end{array}$ & & & \\
\hline 1 & 2 & 3 & 4 & 5 & 6 & 7 \\
\hline \multirow[b]{3}{*}{1} & \multirow[b]{3}{*}{$\begin{array}{l}\text { RP-0085 } \\
\text { SB-2185 }\end{array}$} & \multirow[b]{3}{*}{$\begin{array}{l}\text { Pociąg nr 20, } \\
\text { wózek BP17, } \\
\text { zestawy: } \\
0036,0041\end{array}$} & \multirow{3}{*}{$\begin{array}{c}\text { Przebieg -101375 } \\
\text { km } \\
\text { I faza badań: } \\
\text { Bicie promieniowe } \\
\text { zestawu } 0036 \mathrm{wg} \\
\text { wykresu nr10 - tab. } \\
1 \text { poz. } 12 \\
\text { II faza badań: } \\
\text { Zestawy kołowe } \\
\text { przetoczone }\end{array}$} & $\begin{array}{c}\text { Bezpieczeństwo } \\
\text { jazdy }\end{array}$ & Karta UIC 518 & Pozytywny \\
\hline & & & & Stabilność biegu & Karta UIC 515 & Pozytywny \\
\hline & & & & $\begin{array}{c}\text { Wibracja zestawów } \\
\text { kołowych }\end{array}$ & $\begin{array}{l}\text { Porównawcza analiza } \\
\text { modalna na podstawie } \\
\text { zarejestrowanych postaci } \\
\text { drgań własnych } \\
\text { zestawów taboru typu } \\
\text { „Metropolis” oraz } \\
\text { wyznaczonych dla } \\
\text { taboru rosyjskiego }\end{array}$ & $\begin{array}{l}\text { 1. Koła przetoczone wywołują amplitudy } \\
\text { widma przyspieszeń ok. } 10 \text { razy mniejsze } \\
\text { niż koła w badanym stanie } \\
\text { eksploatacyjnym } \\
\text { 2. Przy podobnej postaci drgań własnych, } \\
\text { amplitudy drgań poprzecznych zestawów } \\
\text { typu „Metropolis” są o ok. } 40 \% \text { większe } \\
\text { od amplitud zestawu „rosyjskiego”. } \\
\text { Zarejestrowane }\end{array}$ \\
\hline 2 & OR-8482 & $\begin{array}{l}\text { Pociagg nr } 20 \\
\text { zestawy: } \\
0040,0042 \\
3077,3079\end{array}$ & $\begin{array}{l}\text { Zestawy nie } \\
\text { przetoczone. } \\
\text { Pozostałe } \\
\text { parametry j.w. }\end{array}$ & $\begin{array}{c}\text { Położenie wózka } \\
\text { względem pudła } \\
\text { wagonu, położenia } \\
\text { zestawów } \\
\text { kołowych } \\
\text { względem ramy } \\
\text { wózka } \\
\end{array}$ & Dokumentacja techniczna & Pozytywny \\
\hline \multirow[b]{3}{*}{3} & \multirow[b]{3}{*}{$\begin{array}{c}501 / \mathrm{E} / 4438 / 1 \\
100 / 000\end{array}$} & \multirow{3}{*}{$\begin{array}{l}\text { 1. Pociąg nr } \\
\text { 19, wózek } \\
\text { BP14, } \\
\text { zestaw: } \\
0001 \text { koło } \\
\text { nr } 23, \\
\text { 2. Pociąg nr } \\
\text { 22, zestaw: } \\
\text { 0052, } \\
\text { 3. } 2 \text { zestawy } \\
\text { zapasowe }\end{array}$} & \multirow{3}{*}{$\begin{array}{c}\text { Przebieg pociagu nr } \\
19 \\
-145201 \mathrm{~km} \\
\text { Bicie promieniowe } \\
\text { zestawu } 0001 \mathrm{wg} \\
\text { wykresu nr } 9-\mathrm{tab} \text {. } \\
1 \text { poz. } 12 \\
\text { Zestaw nr } 0052 \\
\text { przetoczony na } \\
\text { głębokość } 7 \mathrm{~mm}\end{array}$} & $\begin{array}{l}\text { Badania własności } \\
\text { mechanicznych }\end{array}$ & \multirow{2}{*}{ Karta UIC 812-3 } & \multirow{2}{*}{$\begin{array}{c}\text { Wyniki dotyczą koła } \mathrm{nr} 23 \\
\text { Pozytywny z wyjątkiem rozrzutu twardości. } \\
\text { Dopuszczalny rozrzut - } 30 \mathrm{HB} \text {. Rozrzut } \\
\text { zmierzony - } 277 \mathrm{HB} \\
\end{array}$} \\
\hline & & & & $\begin{array}{c}\text { Badania } \\
\text { strukturalne } \\
\end{array}$ & & \\
\hline & & & & $\begin{array}{c}\text { Badania naprężeń } \\
\text { własnych }\end{array}$ & $\begin{array}{l}\text { Karta UIC 812-3 } \\
\text { Standard SNCF } \\
\text { Projekt normy } \\
\text { europejskiej }\end{array}$ & $\begin{array}{l}\text { Wyniki dla obiektów 1,2 i 3_Negatywny w } \\
\text { odniesieniu do standardu SNCF i PrEN } \\
\text { Kryterium UIC jest technicznie wadliwe }\end{array}$ \\
\hline 4 & $\begin{array}{l}\text { Opracowanie } \\
\text { tab.1 poz. } 12\end{array}$ & $\begin{array}{c}\text { Eksploatowa- } \\
\text { ne zestawy nr: } \\
3040,3039, \\
3055,3054, \\
0001,0036, \\
\text { zestawy o } \\
\text { zerowym } \\
\text { przebiegu - } 3 \\
\text { kpl.nowe; } \\
\text { zestawy } \\
\text { "rosyjskie" } \\
\text { porównawcze } \\
\text { - } 2 \text { kpl. } \\
\end{array}$ & - & $\begin{array}{c}\text { bicie } \\
\text { promieniowe }\end{array}$ & $\begin{array}{c}\text { Karta UIC 812-2 } \\
\text { WT eksploatacji } \\
\text { zestawów kołowych - } \\
\text { OW-304 }\end{array}$ & $\begin{array}{l}\text { Wykresy bicia promieniowego. } \\
\text { Wyniki negatywne w proporcji zgodnej do } \\
\text { uzyskanej w p.5 niniejszej tabeli }\end{array}$ \\
\hline 5 & $\begin{array}{c}\text { Protokół } \\
\text { tab.1 poz. } 13\end{array}$ & $\begin{array}{l}\text { Wszystkie } \\
\text { koła } \\
\text { wszystkich } \\
\text { pociaggów wg } \\
\text { tab. } 2\end{array}$ & $\begin{array}{c}\text { Dla części } \\
\text { pomiarów (tab. } 2 \text { ) } \\
\text { udokumentowane } \\
\text { bicie promieniowe } \\
\text { wg wykresów } 8 \div 14 \\
\text { - tab.1 poz. } 12 . \\
\end{array}$ & $\begin{array}{l}\text { Pomiary twardości } \\
\text { na powierzchni } \\
\text { tocznej }\end{array}$ & Karta UIC 812-3 & $\begin{array}{l}\text { Liczba kół objętych pomiarami - } 384 \text {. } \\
\text { Wynik negatywny dla - } 41 \% \text { kół. } \\
\text { Potwierdzona zbieżność wyników z biciem } \\
\text { promieniowym. }\end{array}$ \\
\hline 6 & $\begin{array}{l}\text { Memoran- } \\
\text { dum } \\
\text { tab. } 1 \text { poz. } 7\end{array}$ & $\begin{array}{l}\text { Pociag nr 19, } \\
\text { wózek BP14, } \\
\text { zestaw: } 0001 \\
\text { koło } \mathrm{nr} 20 \text {, }\end{array}$ & $\begin{array}{l}\text { Udokumentowany } \\
\text { (wykres nr } 9 \text { - tab.1 } \\
\text { poz. 12) brak bicia } \\
\text { promieniowego }\end{array}$ & $\begin{array}{l}\text { Pomiary twardości } \\
\text { na powierzchni } \\
\text { tocznej }\end{array}$ & Karta UIC 812-3 & Pozytywny \\
\hline 7 & $\begin{array}{c}\text { Raport } \\
\text { nr } 18040101\end{array}$ & $\begin{array}{l}\text { Całość taboru } \\
\text { metra typu } \\
\text { "Metropolis" }\end{array}$ & $\begin{array}{l}\text { Wykaz usterek } \\
\text { następujących } \\
\text { zestawów } \\
\text { kołowych: } \\
0017,3003,3008 \\
3011,0011,0038 \\
0033,0005,3001 \\
3093,3092,0065 \\
\end{array}$ & opis usterek & - & $\begin{array}{c}\text { z } 12 \text { opisanych uszkodzeń pow. tocznej } \\
\text { zestawów } 6 \text { zakwalifikowano jako skutek } \\
\text { awarii sterowania hamulcem }\end{array}$ \\
\hline
\end{tabular}

dążenie do obniżenia poziomu naprężeń własnych kierując się znanymi i stosowanymi kryteriami np.SNCF.

Zakładając, że rozwiązanie wyżej omówionego problemu jest konieczne, można przyjąć, że nastąpi istotna i korzystna zmiana $\mathrm{w}$ odniesieniu do problemu drugiego i związanych z nim wszystkich dotychczas nie spełnianych wymagań (pkt. 5). Zważywszy jednak, że badania miały charakter rozpoznawczy, że nie są znane ilościowe zakresy wpływu obu podstawowych przyczyn, nie jest obecnie możliwe twierdzenie, że dzięki eliminacji nadmiernych naprężeń własnych nastąpi radykalne rozwiązanie problemu. W związku z tym należy podjać działania ochronne o skutku identycznym $\mathrm{z}$ działaniami technicznymi, a więc zmienić charakter procedur obsługowych z przystających do dobrze funkcjonującej konstrukcji pojazdu na procedury zapobiegawcze, odpowiadające rzeczywistym możliwościom konstrukcyjnym taboru.

W tym celu należy:

- ustalić inne parametry procedur obsługowych opierając je na monitoringu drgań zestawów kołowych, 
- ustalić kryteria oceny drgań,

- wprowadzić system ekonomicznych przetaczań reprofilujących.

Wymiar czasowy proponowanych wyżej działań będzie z natury rzeczy rozległy. Jest więc zasadną myśl, aby kontynuować i rozwinąc wstępną pracę eksperta do wymiaru, pozwalającego na ilościową ocenę wpływu naprężeń własnych na proces nieregularnego zużycia okręgów tocznych zestawów kołowych taboru typu "Metropolis".

\section{Wnioski końcowe}

1. W zakresie bezpieczeństwa jazdy i stabilności biegu (karty UIC 515 oraz UIC 518) tabor typu "Metropolis" spełnia wymienione wymagania i może być eksploatowany.

2. Eksploatacja taboru metra typu "Metropolis" zgodna $\mathrm{z}$ technicznymi procedurami obsługowymi producenta prowadzi do nieregularnego zużycia powierzchni tocznej kół powodującego:

- przekroczenie kryteriów dopuszczalnych drgań wg PN-88/B-02171, w odniesieniu do ludzi znajdujących się w budynkach,

- różnicowanie twardości powierzchni tocznej kół, uniemożliwiające prawidłowe wykonywanie technologicznych zabiegów reprofilujących,

- 20 - krotny, w stosunku do koła o regularnym zarysie, wzrost amplitudy drgań pionowych mierzony na maźnicy zestawu kołowego, niekorzystnie wpływając na wytrzymałość zmęczeniowa, przede wszystkim zestawów kołowych,

- zmniejszenie żywotności kół.

3. Wysoki poziom naprężeń własnych kół zestawów wagonowych, w stosunku do standardów SNCF i PrEN, realnie grozi miejscową, sprężystą utratą stabilności tarczy koła. W związku z tym:
- następuje potęgowanie zjawiska nieregularnego zużycia powierzchni tocznej kół,

- powstają uszkodzenia zmęczeniowe powierzchni tocznych kół.

Z wymienionych powodów konieczne jest aby:

3.1 w odniesieniu do kół nowych poziom naprężeń własnych kół mieścił się w granicach $-80 \mathrm{MPa} \div-$ $150 \mathrm{MPa}$ i jednocześnie należy dążyć do uzyskania nominalnej twardości wieńca koła minimum $300 \mathrm{HB}$.

3.2 w odniesieniu do kół eksploatowanych dokonać pomiaru naprężeń własnych wszystkich kół i selekcji w oparciu o kryterium naprężeń własnych wg pkt 3.1.

4. Eksploatacja taboru typu "Metropolis" na poziomie odpowiadającym jego rzeczywistym możliwościom technicznym wymaga:

- wprowadzenia procedur obsługowych opierających się na monitoringu drgań zestawów kołowych,

- ustalenia kryteriów oceny drgań,

- wprowadzenia systemu ekonomicznych przetaczań reprofilujących.

5. Z uwagi na powszechność zjawiska nieregularnego zużycia powierzchni tocznej kół uważa się, że jest to wada systemowa konstrukcji zestawu kołowego taboru typu "Metropolis" eksploatowanego w Metrze Warszawskim w 2002 roku. W omawianym przypadku za wadę systemową należy uważać brak spójności konstrukcji z wymaganiami eksploatacyjnymi.

\section{Podsumowanie.}

Opisane prace i wynikające $\mathrm{z}$ nich hipotezy stały się podstawą dalszych wspólnych działań producenta i użytkownika, doskonalących konstrukcję i system eksploatacyjny taboru typu „Metropolis”. 


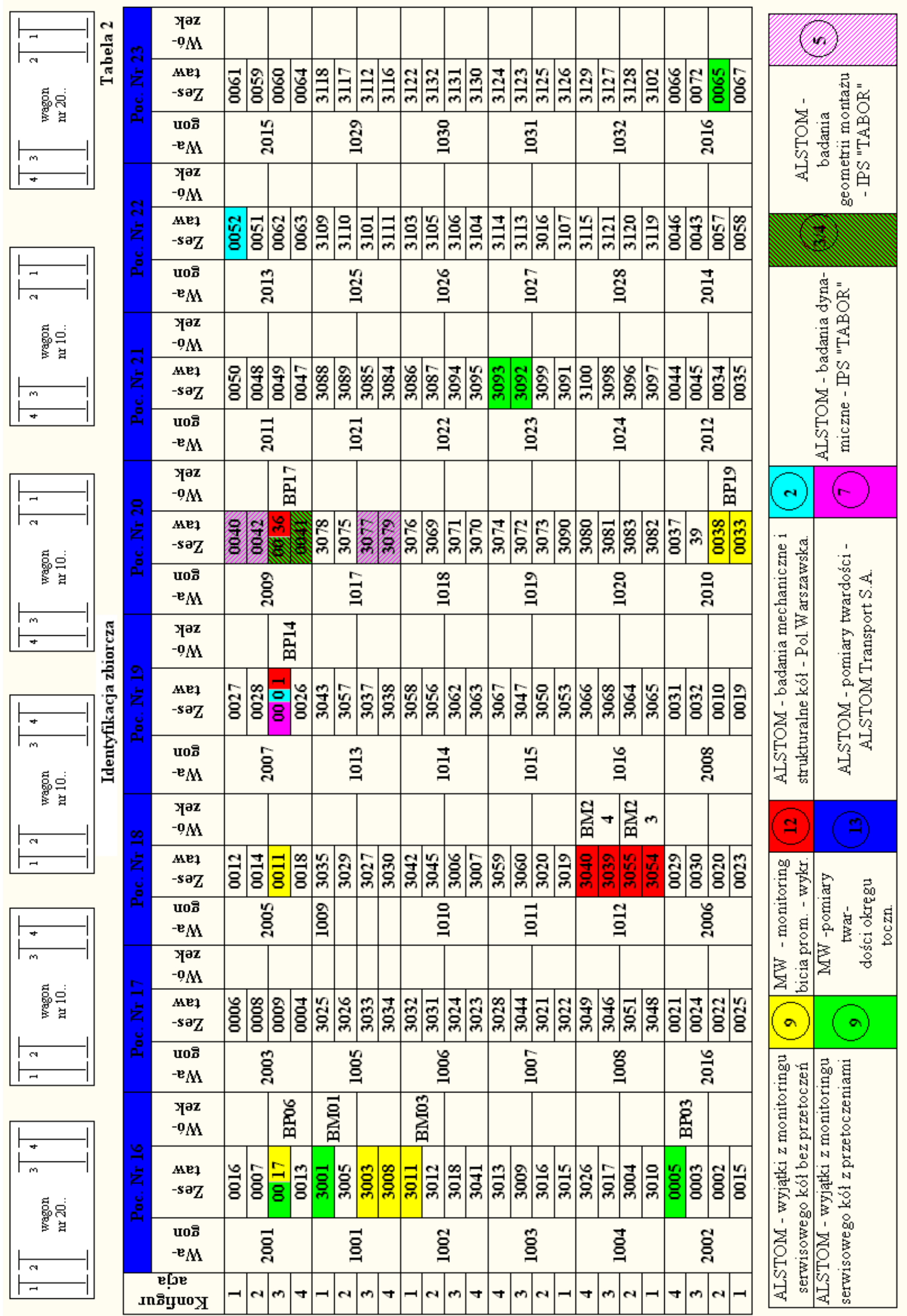

